\title{
Identifikasi Daerah Kerawanan Kebakaran Hutan dan Lahan Menggunakan Sistem Informasi Geografis dan Penginderaan Jauh di Kawasan Tanjung Jabung Barat Provinsi Jambi
}

\author{
As'ad Humam $^{1 *}$, Masrul Hidayat ${ }^{1}$, Arsy Nurrochman ${ }^{1}$, Ade Irma Anestatia ${ }^{1}$, Aisyah Yuliantina ${ }^{1}$, \\ Salomo Pranata Aji ${ }^{2}$
}

'Jurusan Teknik Geofisika, Universitas Lampung, Jl. Prof. Dr. Sumantri Brojonegoro No.1, Bandar Lampung 35415

${ }^{2}$ Jurusan Teknologi Pertanian, Politeknik Negeri Lampung, Jl. Soekarno Hatta No.10, Bandar Lampung 35141

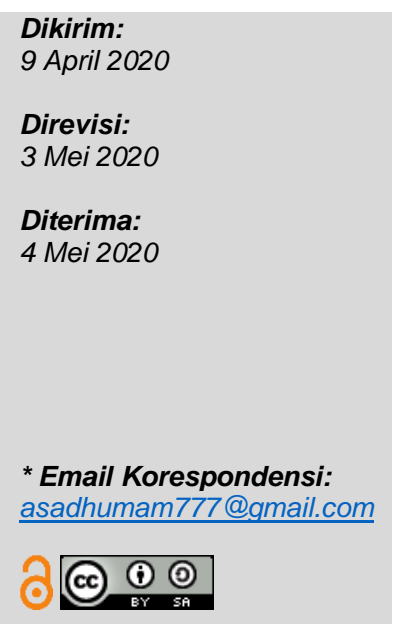

Abstrak: Bentang luas kawasan gambut provinsi Jambi berkisar 621.000 ha dan luas hutan 2.107.779 ha. Sebaran lahan gambut terdapat pada kawasan kabupaten bagian hilir serta bagian pantai timur Sumatera yaitu Kabupaten Tanjung Jabung Timur (46\%), Kabupaten Muaro Jambi (30\%) dan Kabupaten Tanjung Jabung Barat (20\%) maka, sangat diperlukan untuk menganalisis daerah tersebut secara geospasial serta membuat skenario kerawanan kebakaran hutan dan lahan. Terdapat 7 parameter untuk membuat peta kerawanan kebakaran hutan dan lahan yaitu suhu udara, akses jalan, akses sungai, kepadatan hotspot, peruntukan lahan, curah hujan, dan penggunaan lahan. Ketujuh parameter tersebut diklasifikasikan serta dilakukan koreksi citra Landsat 8 yang kemudian dibobotkan dengan melalui proses Weighted Overlay. Hasil proses Weighted Overlay menghasilkan peta kerawanan kebakaran hutan dan lahan. Peta kerawanan kebakaran hutan dan lahan menghasilkan 3 kelas yaitu sangat rawan, sedang, dan tidak rawan. Skenario tersebut menghasilkan peta kerawanan kebakaran hutan wilayah dengan potensi sangat rawat berada pada daerah Desa Senyeran dan Pengabuan dengan luas wilayah 35.068 ha.

Kata kunci: Analisis Geospasial, Weighted Overlay, Penginderaan Jauh, Kebakaran Hutan dan Lahan, Sistem Informasi Geografis

\begin{abstract}
The total area of peatlands in Jambi Province is around 621.000 ha and the forest area is 2.107.779 ha. The wide area of peatlands can be found in coastal distric and the East Coast of Sumatra, that is East Tanjung Jabung District (46\%), Muaro Jambi Distric (30\%) and West Tanjung Jabung District (20\%) therefore, it's necessary to analyze that regency in geospatial way and make a scenario forest and land fire vulnerability. There are 7 parameters to create a map of forest and land vulnerability, namely air temperature, road access, river access, hotspot density, land allocation, rainfall, and land use. The seven parameters are classified and corrected citra Landsat 8 and then Weighted through a Weighted Overlay process. From the results of Weighted Overlay process then will be get the map of forest and land fire vulnerability. Map of forest and land fire produce 3 classes, very vulnerable, moderate, and not vulnerable. From the result of scenario, map of the forest fire vulnerability areas with very vulnerable potential are Senyeran and Pengabuan Villages with an area of 45.068 ha.
\end{abstract}

Keywords: Forest and Land Fire, Geographic Information System, Geospasial Analysis, Remote Sensing, Weighted Overlay

\section{PENDAHULUAN}

Bencana kebakaran hutan dan lahan yang semakin marak terjadi sangat mengganggu karena menghasilkan emisi khususnya di Indonesia sebagai Negara tropis. Kebakaran hutan dan lahan dapat terjadi berdasarkan 2 faktor utama yaitu faktor alami dan faktor yang dilakukan manusia, faktor alami dapat berupa kemarau panjang sehingga tanaman menjadi kering dan kegiatan manusia berupa pembakaran liar untuk memperluas lahan (Rasyid, 2014). Bencana ini memiliki skala kerugian yang besar, bukan hanya dari segi ekonomi, kesehatan, bahkan menyangkut proses keberlanjutan pertumbuhan tanaman. Berdasarkan BNPB bentang alam kawasan gambut di Provinsi Jambi berkisar 621.000 ha dan luas hutan 2.107.779 ha. Luas hutan rawa gambut di Pulau Sumatera $7,4 \%$ nya terletak di Provinsi Jambi sedangkan luas wilayah kabupaten Tanjung Jabung Barat berkisar 500.982 ha. Wahana Lingkungan Hidup (Walhi) menyampaikan kerugian akibat dari kebakaran hutan dan lahan ISSN 2722-3647 ISSN 2722-3639 (e) gambut di Provinsi Jambi mencapai Rp.145 triliun. Nilai kerugian tersebut, dihitung berdasarkan luas lahan gambut terbesar dan rusak seluas 114 ribu ha yang terjadi dalam kurun waktu tahun 2019. Sebaran lahan gambut terdapat pada berbagai kabupaten yang berada di kawasan hilir serta bagian gugus pantai timur Sumatera yaitu terdiri dari Kabupaten Tanjung Jabung Timur (46\%), Kabupaten Muaro Jambi (30\%) dan Kabupaten Tanjung Jabung Barat (20\%) (Oktiana dkk, 2017).

Berdasarkan data titik panas tahun 2003 dinas kehutanan terdeteksi titik panas sebanyak 1.678 dengan luas kawasan sebesar 3.025 ha dalam keadaan terbakar, kejadian terulang kembali pada tahun 2006 dengan jumlah titik panas sebanyak 6.948 yang tersebar pada 8 kabupaten Provinsi Jambi (Widodo, 2014). Berdasarkan pemantauan Satelit Nasional Oceanic Atsmospheric Administration (NOAA) terdapat 18 sebaran titik di provinsi pada areal masyarakat, areal hutan tanaman industri, areal kelapa sawit, hutan lindung dan lahan gambut. Kebakaran di dukung oleh faktor Available online at https://jgrs.eng.unila.ac.id/ DOI: https://doi.org/10.23960/igrs.2020.v1i1.14 
luar seperti pemanasan global, kemarau jangka panjang memberikan kondisi ideal untuk terjadinya kebakaran hutan dan lahan (Syarif dkk., 2019). Selain itu, hasil kajian lainnya menyebutkan bahwa gambut merupakan kontributor terbesar 85\% terhadap total emisi Jambi bersama sektor kehutanan.

Penginderaan jarak jauh merupakan ilmu serta seni untuk mendapatkan beragam informasi berupa objek, daerah, menganalisis sebuah data dengan alat tanpa kontak langsung dengan objek, daerah dan kajian yang dianalisis (Utomo, 2017). Sistem informasi geografis merupakan pemrosesan data spasial dengan berbasis komputer yang sudah tergeoreferensi serta disimpan dalam suatu basis data dan berkaitan dengan keadaan dunia nyata (Masykur, 2014).

Secara rinci tujuan dilakukannya penelitian ini adalah (1) menyusun peta kerawanan kebakaran hutan dan lahan di wilayah Tanjung Jabung Barat, Provinsi Jambi skala 1:250.000 dengan memanfaatkan informasi geografis, penginderaan jauh, dan analisis data sekunder, (2) menganalisis pembobotan serta pengaruh masing-masing informasi geografis dan penginderaan jauh terhadap kerawanan kebakaran di wilayah Tanjung Jabung Barat, Provinsi Jambi, (3) menyusun peta skenario kerawanan kebakaran hutan dan lahan Tanjung Jabung Barat, Provinsi Jambi berdasarkan proses Weighted Overlay untuk memetakan daerah yang berpotensi sebagai pusat kerawanan kebakaran hutan dan lahan.

\section{BAHAN DAN METODE PENELITIAN}

Secara umum parameter yang digunakan untuk melakukan penelitian terkait peta kerawanan kebakaran hutan dan lahan terdiri dari 7 parameter yaitu tingkat curah hujan, suhu, akses terhadap sungai, akses terhadap jalan, kepadatan hotspot tahun 2019, tutupan lahan atau penggunaan lahan dan peruntukan lahan. Kemudian dilakukannya proses pembobotan dengan memanfaatkan toolbox pada ArcGIS yaitu Weighted Overlay dengan penilaian influence dan pengkelasan masingmasing parameter. Alat dan bahan yang digunakan berupa Software ArcGIS Versi 10.3, Citra Landsat 8 pada 16 September 2019. Secara lebih terperinci metode yang digunakan adalah sebagai berikut:

\subsection{Koreksi Citra}

Koreksi citra dilakukan untuk mengolah data dalam bentuk raster yang diperhitungkan parameter-parameter di dalamnya untuk mendapatkan nilai dari apa yang dikoreksi berdasarkan pemanfaatan metadata. Pada penelitian kali ini berikut merupakan koreksi citra yang digunakan terdiri dari.

\subsubsection{Koreksi Radiometri Citra Satelit}

Koreksi radiometri merupakan teknik untuk memperbaiki data citra untuk menghilangkan pengaruh atmosferik yang menimbulkan kenam- pakan bumi secara tidak tajam (Sari dkk., 2017). Koreksi radiometri dilakukan untuk memperbaiki hasil rekaman satelit yang mengalami kesalahan akibat adanya gangguan atmosfer. Gangguan yang disebabkan oleh atmosfer menyebabkan penyimpangan sudut pantul terhadap penerimaan sensor pada satelit. Koreksi radiometri digunakan untuk menyusun kembali pantulan yang direkam oleh sensor memperkecil penyimpangan sehingga mempunyai pola pantul seperti keadaan objek yang sebenarnya (Parman, 2010). Koreksi ini dapat dilakukan dengan menggunakan persamaan berikut:

$$
\rho_{\lambda}^{\prime}=M \rho^{*} Q_{\text {cal }}+A_{\rho}
$$

\section{Di mana:}

$\begin{array}{ll}\rho_{\lambda}{ }^{\prime} & : \text { TOA planetary spectral reflectance } \\ M \rho & : \text { Reflectance multiplicative band } \\ Q_{\text {cal }} & : \text { L1 pixel value in DN } \\ A_{\rho} & : \text { Refletance additive band }\end{array}$

Pada Landsat 8 koreksi radiometri reflectance harus dilanjutkan dengan menambahkan solar elevation angel untuk mendapatkan koreksi radiometri reflectance yang sebenarnya, dengan rumus:

$$
\rho_{\lambda}=\frac{\rho_{\lambda^{\prime}}}{\operatorname{Sin}(\theta)}
$$

Di mana:

$$
\begin{array}{ll}
\rho_{\lambda} & : \text { TOA planetary reflectance (Unitless) } \\
\theta & : \text { Solar elevation angle }
\end{array}
$$

Reflektan ToA (Top of Atmospheric) merupakan nilai reflektan yang ditangkap oleh sensor pada satelit sedangkan BoA (Bottom of Atmospheric) merupakan reflektan objek yang terkoreksi atmosfer, reflektan ToA didapatkan melalui proses koreksi radiometri (Kristianingsih dkk., 2016). Koreksi radiometri juga dapat dilakukan pada citra Landsat 7 dan 8, tujuan yaitu mengubah data digital number DN ke radiasi yang ditangkap oleh sensor satelit sehingga menjadi Top of Atmosferic (ToA) Radiance, di mana formula TOA radiance sebagai berikut:

$$
L_{\lambda}=M_{L}^{*} Q_{c a l}+A_{L}
$$

Di mana:

$L_{\lambda} \quad:$ Spectral radiance $\left(\mathrm{W} /\left(\mathrm{m}^{2 *} \mathrm{sr}^{*} \mu \mathrm{m}\right)\right)$

$M_{L} \quad$ : Radiance multiplicative band

$A_{L} \quad:$ Radiance additive band

$Q_{\text {cal }} \quad:$ L1 pixel value $D N$

Setalah mendapatkan nilai TOA radiance atau spectral radiance maka selanjutnya melakukan perhitungan Top of Atmosphere Brightness Temperature, dengan formula :

$$
T B=\frac{K_{2}}{\ln \left(\frac{K_{1}}{L_{\lambda}}+1\right)}-273,15
$$

\section{Di mana:}

TB : At brightness temperature 
$K_{2} \quad$ : Band-spesific thermal conversion from metadata $\left(K_{2}\right.$ _Constant_Band_ $x$, where $x$ is thermal band number, 10 or 11 )

$K_{1} \quad$ : Band-spesific thermal conversion from metadata ( $K_{1}$ _Constant Band_ $x$, where $x$ is thermal band number, 10 or 11$)$

$L_{\lambda} \quad$ : TOA spectral radiance $\left(\mathrm{W} /\left(\mathrm{m}^{2 *} \mathrm{sr}^{*} \mu \mathrm{m}\right)\right)$ Nilai at brightness temperature yang terdapat pada band 10 dan 11, akan dikalkulasikan kembali untuk mendapatkan nilai at brightness temperature rata-rata yang akan digunakan untuk pengolahan coversion brightness temperature to surface temperature.

\subsubsection{Metode NDVI}

Metode NDVI (Normalized Difference Vegetation Index) merupakan metode untuk mengetahui kerapatan dari vegetasi, indeks kehijauan maupun aktivitas fotosintesis vegetasi. Indeks vegetasi didasarkan berdasarkan pengamatan permukaan yang memiliki refleksi berbeda-beda serta jenis gelombang cahaya. Vegetasi aktif dalam fotosintesis akan menyerap gelombang merah dari matahari dan mencerminkan inframerah lebih banyak, sedangkan vegetasi yang sudah layu atau mati banyak mencerminkan gelombang merah namun sedikit mencerminkan gelombang inframerah. (Andini dkk., 2018). Metode NDVI dilakukan dengan rumus:

$$
N D V I=\frac{(N I R-V I S)}{N I R+V I S} ; N D V I=\frac{(N I R-R E D)}{N I R+R E D}
$$

Di mana:

NIR : Gelombang inframerah dekat

RED : Gelombang merah

Berdasarkan citra Landsat 8 dan 7, dalam menentukan metode NDVI perlu diperhatikan kembali susunan band NIR dan RED. Pada Landsat 8 , NIR terdapat pada band 5 dan RED terapat pada band 4, sedangkan pada Landsat 7 NIR terdapat pada band 4 dan RED terdapat pada band 3 . Rentang nilai NDVI yang akan digunakan pada penelitian kali ini dapat dilihat pada tabel 1 .

Tabel 1. Klasifikasi NDVI (Wahyunto dkk., 2014)

\begin{tabular}{cc}
\hline $\begin{array}{c}\text { Rentang } \\
\text { Klasifikasi }\end{array}$ & Kerapatan \\
\hline$-1<\mathrm{NDVI}<-0,03$ & $\begin{array}{c}\text { Lahan tidak } \\
\text { bervegetasi } \\
\text { Kehijauan sangat } \\
\text { rendah }\end{array}$ \\
$-0,03<\mathrm{NDVI}<0,15$ & Kehijauan rendah \\
$0,15<\mathrm{NDVI}<0,25$ & Kehijauan sedang \\
$0,25<\mathrm{NDVI}<0,35$ & Kehijauan tinggi \\
$0,35<\mathrm{NDVI}<1$ &
\end{tabular}

Setelah mendapatkan nilai NDVI maka proses selanjutnya yaitu melakukan penurunan NDVI untuk mendapatkan proporsi vegetasi agar mendapatkan nilai emisivitas, yaitu dengan rumus:

$$
P V=\left(\frac{N D V I-N D V I_{\min }}{N D V I_{\max }-N D V I_{\min }}\right)^{2}
$$

Di mana:

$P V \quad$ : Prosposi vegetasi

$N D V I_{\min }:$ Nilai NDVI terendah

$N D V I_{\text {max }}$ : Nilai NDVI tertinggi

\subsubsection{Metode Suhu Permukaan}

Temperatur permukaan tanah atau LST merupakan keadaan pada keseimbangan energi permukaan, atmosfer, sifat suhu pada permukaan, dan media bawah permukaan, LST (Land Surface Temperature) diidentifikasikan dari citra Landsat berdasarkan band thermal (Delarizka dkk., 2016). Metode untuk menentukan suhu permukaan yaitu mentransformasi suhu dengan memanfaatkan nilai proporsi vegetasi untuk mencari nilai land surface emissivity, dengan rumus sebagai berikut:

$$
L S E=0,004 P V+0,989
$$

Setelah mendapatkan nilai land surface emissivity, maka dilakukan transformasi untuk mendapatkan nilai suhu permukaan, dengan rumus yaitu:

$$
L S T=\frac{T B}{1+\left(\lambda^{*} \frac{T B}{C 2}\right) * \ln (e)}
$$

Di mana:

$$
\begin{array}{ll}
\text { LST } & \text { : Land Surface Temperature } \\
T B & : \text { Brightness Temperature } \\
\lambda & : \text { Wavelength of emitted radiance } \\
C 2 & : \mathrm{h}^{*} \mathrm{c} / \mathrm{s}=1.4388^{*} 10^{-2} \mathrm{~m} \mathrm{k}: 14388 \mu \mathrm{m} \mathrm{k} \\
s & : \text { Boltzmann constant }: 1.38^{*} 10^{-23} \mathrm{~J} / \mathrm{K} \\
e & : \text { emissivity }
\end{array}
$$

\subsection{Pembuatan Peta Kerawanan}

Peta kerawanan dibuat untuk digunakan sebagai media perantara dalam melakukan sebuah analisis terkait potensi kerawanan kebakaran lahan dan hutan. Peta kerawanan pada penelitian ini terdiri dari.

\subsubsection{Suhu Udara}

Suhu merupakan salah satu parameter utama untuk menentukan potensi kerawanan suatu wilayah. Suhu dapat diasumsikan sebagai bentuk pembuatan pada peta suhu permukaan, apabila suatu wilayah memiliki suhu yang tinggi maka wilayah tersebut memiliki kerawanan yang lebih besar dibandingkan dengan suatu wilayah yang memiliki suhu relatif lebih kecil. Peta suhu permukaan didapatkan dengan melakukan transformasi pengolahan citra berupa koreksi radiansi yang dilanjutkan untuk menemukan brightness temperature, nilai brightness temperature diguna- 
kan untuk mendapatkan nilai suhu permukaan (LST). Proses transformasi pada suhu permukaan menggunakan data citra Landsat 8, dengan memanfaatkan band 10 atau 11, serta diolah berdasarkan rumus yang sudah dijelaskan sebelumnya. Peta suhu permukaan yang didapat dari hasil transformasi koreksi citra, kemudian dilakukan pengklasifikasian dengan tools classify pada ArcMap. Kelas yang akan digunakan untuk mengklasifikasi peta suhu permukaan dibagi menjadi 5 kelas yakni:

Tabel 2. Klasifikasi Suhu Permukaan

\begin{tabular}{cc}
\hline Kelas & Suhu \\
\hline Kelas 1 & $21-25^{\circ}$ \\
Kelas 2 & $26-30^{\circ}$ \\
Kelas 3 & $31-34^{\circ}$ \\
Kelas 4 & $35-39^{\circ}$ \\
Kelas 5 & $41-44^{\circ}$ \\
\hline
\end{tabular}

\subsubsection{Curah Hujan}

Curah hujan merupakan salah satu aspek penting dalam melakukan analisis geospasial, terkhususnya untuk membuat peta sebaran curah hujan. Peta sebaran curah hujan dapat digunakan untuk menganalisis potensi kerawanan kebakaran hutan dan lahan. Semakin tinggi tingkat curah hujan suatu wilayah maka, semakin rendah tingkat kerawanan kebakaran pada wilayah tersebut. Data curah hujan didapatkan melalui Center for Hydrometeorology and Remote Sensing pada tahun akuisisi 2019 dengan data berupa rata-rata curah hujan daerah Jambi selama 2018-2019.

Data yang didapatkan berupa data raster yang kemudian dilakukannya interpolasi pada ArcMap di wilayah penelitian. Peta curah hujan yang didapat hasil interpolasi, selanjutnya dilakukan proses pengklasifikasian dengan menggunakan tool classify. Dihasilkan 5 kelas kerawanan berdasarkan curah hujan dengan metode interval dan menghasilkan pengkelasan sebagai berikut:

Tabel 3. Klasifikasi Curah Hujan

\begin{tabular}{cc}
\hline Kelas & Curah Hujan \\
\hline Kelas 1 & $563-678 \mathrm{~mm} /$ tahun \\
Kelas 2 & $448-563 \mathrm{~mm} /$ tahun \\
Kelas 3 & $332-448 \mathrm{~mm} /$ tahun \\
Kelas 4 & $217-332 \mathrm{~mm} /$ tahun \\
Kelas 5 & $101-217 \mathrm{~mm} /$ tahun \\
\hline
\end{tabular}

\subsubsection{Jaringan Sungai}

Jaringan sungai sangat berpengaruh terhadap kerawanan kebakaran. Jaringan sungai berguna sebagai akses pemadaman apabila terjadinya kebakaran hutan. Kebakaran hutan dan lahan memiliki intensitas yang besar maka diperlukannya akses berupa sungai untuk memadamkannya, semakin akses sungai berdekatan maka semakin cepat proses pemadamannya. Kebakaran hutan dan lahan tidak bias dipadamkan hanya mengandalkan kolam dan air berskala kecil.

Keberadaan sungai sangat berpotensi untuk pemadaman, apabila jarak sungai saling berdekatan maka akan membantu dalam proses pemadaman hutan berskala besar. Pembuatan peta jaringan sungai dapat dilakukan dengan melalui proses multiple ring buffer yang berada pada menu toolbox pada ArcMap. Hasil dari proses Multiple Ring Buffer akan menciptakan jarak sungai yang kemudian dapat dilakukan pengkelasan yaitu dengan melakukan proses classify pada menu toolbox. Jaringan sungai dapat dikelaskan sebagai berikut:

Tabel 4. Klasifikasi Jaringan Sungai

\begin{tabular}{cc}
\hline Kelas & Jarak Sungai \\
\hline Kelas 1 & $0-2 \mathrm{Km}$ \\
Kelas 2 & $2-5 \mathrm{Km}$ \\
Kelas 3 & $5-10 \mathrm{Km}$ \\
\hline
\end{tabular}

\subsubsection{Jaringan Jalan}

Jaringan jalan merupakan parameter penting dalam melakukan analisis potensi kerawanan kebakaran hutan dan lahan. Peran jaringan jalan sebagai akses untuk melakukan pemadaman, serta semakin jauh jaringan jalan maka semakin jauh kawasan tersebut dari pemukiman. Sehingga potensi kerawanan meningkat sepanjang akses jaringan jalan yang ada di wilayah tersebut. Semakin jauh jaringan jalan maka tingkat kerawanan akan semakin besar, semakin dekat jaringan jalan maka akses membuat tingkat kerawanan akan semakin mengecil.

Pembuatan peta jaringan jalan dapat dilakukan dengan memanfaatkan tools pada ArcMap berupa Multiple Ring Buffer. Tools ini berfungsi sebagai penganalisa jarak akses jalan sepanjang ketentuan yang disepakati. Peta jaringan jalan yang sudah dilakukan proses Mutiple Ring Buffer kemudian dapat dilanjutkan dengan proses pengkelasan dengan tools classify, Pengkelasan jaringan jalan sebagai berikut:

Tabel 5. Klasifikasi Jaringan Jalan

\begin{tabular}{cc}
\hline Kelas & Jarak Jalan \\
\hline Kelas 1 & $0-2 \mathrm{Km}$ \\
Kelas 2 & $2-5 \mathrm{Km}$ \\
Kelas 3 & $5-10 \mathrm{Km}$ \\
Kelas 4 & $10-15 \mathrm{Km}$ \\
Kelas 5 & $>15 \mathrm{Km}$ \\
\hline
\end{tabular}




\subsubsection{Kepadatan Hotspot}

Kepadatan hotspot memiliki peranan penting dalam kerawanan kebakaran, semakin besar kepadatan hotspot temporal maka akan memberikan tingkat kerawanan yang tinggi dibandingkan dengan wilayah yang sedikit menunjukan kepadatan hotspot temporal. Kepadatan hotspot merupakan titik panas yang terjadi pada suatu pemukiman yang dapat menimbulkan terjadinya potensi kerawanan kebakaran hutan dan lahan. Data hotspot dapat diperoleh melalui akses Lembaga Penerbangan dan Antariksa Nasional dari tahun 2010 hingga 2019. Peta kepadatan penduduk dapat dibuat dengan penggunaan data hotspot melalui proses point density pada ArcMap dan diklasifikasi menjadi 4 kelas berdasarkan equal interval kepadatanya. Berdasarkan equal interval terdapat 4 kelas pada kelas 1 hingga 4 berupa sangat jarang, sedang, padat, sangat padat.

\subsubsection{Peruntukan Lahan}

Peruntukan lahan merupakan salah satu bentuk kerawanan kebakaran hutan dan lahan, dengan melakukan pemetaan terhadap keberadaan lahan gambut serta penggunaannya. Lahan gambut merupakan lahan yang sangat mudah mengalami proses pembakaran sehingga memungkinkan sebagai penyebab terjadinya kebakaran hutan dan lahan. Lahan gambut terdiri dari 2 jenis lahan gambut kering dan basah, lahan gambut kering sangat berpotensi tinggi untuk terjadinya pembakaran berskala sangat cepat dalam hal perambatan, sedangkan pada lahan gambut basah tidak terlalu cepat dalam penyebaran kebakaran hutan dan lahan.

Peta peruntukan lahan dapat dibentuk dengan memanfaatkan analisis geospasial yang dipadukan dengan informasi geologi daerah setempat serta penggunaan data RBI. Maka dari itu proses pembuatan peruntukan lahan gambut sangat penting untuk dilaksanakan, karena gambut merupakan penyebab kebakaran hutan berskala besar akibat cepatnya perambatan api pada lahan gambut. Informasi yang dapat ditampilkan dapat berupa kawasan non-gambut yaitu kawasan yang tidak terdapat gambut, kawasan gambut IUPHHKHTI (Izin Usaha Pemanfaatan Hasil Hutan Kayu Hutan Tanaman Industri) yang digunakan untuk informasi peruntukan lahan.

Berdasarkan analisis geospasial diasumsikan selain daerah di luar kawasan konservasi lahan gambut dan IUPHHK-HTI merupakan kawasan gambut APL (Areal Penggunaan Lahan). Gambut APL memiliki potensi yang sangat besar sebagai penyebab tingginya potensi kebakaran hutan, hal ini disebabkan karena kawasan gambut APL merupakan lahan gambut terbuka tidak adanya perawatan sehingga dapat memungkinkan terjadinya kebakaran hutan. Berdasarkan peta peruntukan lahan dapat diklasifikasi menjadi 4 kelas. Pada kawasan non-gambut merupakan kawasan kelas 1 karena memungkinkan untuk tidak terjadinya kebakaran hutan. Pada kawasan Konservasi me- rupakan kawasan kelas 2 berdasarkan tingkat potensi terjadinya kebakaran hutan. Pada kawasan gambut IUPHHK-HTI merupakan kelas 3, lahan gambut yang memiliki izin juga dapat menjadi salah satu potensi besar terjadinya kebakaran hutan. Pada kawasan gambut APL merupakan kawasan kerawanan dengan kelas 4 yaitu kelas paling rawan untuk terjadinya kebakaran hutan.

\subsubsection{Penggunaan Lahan}

Penggunaan lahan atau penutupan lahan merupakan salah satu potensi yang menyebabkan kerawanan kebakaran lahan dan hutan. Citra Landsat 8 diklasifikasikan menjadi 6 jenis penggunaan lahan atau tutupan lahan yaitu vegetasi rapatan tinggi, vegetasi rapatan sedang, tubuh air, lahan terbangun, lahan terbuka, dan awan serta bayangan awan (Fawzi, 2014). Peta penggunaan lahan dapat dibuat berdasarkan analisis geospasial dengan memanfaatkan peta RBI yang mengandung informasi-informasi terkait penggunaan lahan wilayah Tanjung Jabung Barat.

Peta penggunaan lahan juga dibuat berdasarkan parameter kerapatan vegetasi pada analisis NDVI citra satelit untuk mengetahui persebaran hutan lahan. Berdasarkan pembuatan peta penggunaan lahan dapat diklasifikasinya dengan menggunakan tools classify dengan parameter kelas sebagai berikut:

Tabel 6. Klasifikasi Penggunaan Lahan

\begin{tabular}{|c|c|c|}
\hline Penutupan Lahan & Kelas & Klasifikasi \\
\hline $\begin{array}{l}\text { Hutan lahan kering se- } \\
\text { kunder, Landclearing } \mathrm{HTI} \\
\text { Landclearing perkebunan }\end{array}$ & $\begin{array}{l}\text { Sangat } \\
\text { Rawan }\end{array}$ & $\begin{array}{c}\text { Kelas } \\
\text { Kerawanan } \\
\quad 4\end{array}$ \\
\hline $\begin{array}{l}\text { Hutan mangrove sekun- } \\
\text { der, Hutan rawa sekun- } \\
\text { der, Pertanian lahan ke- } \\
\text { ring campur semak, Se- } \\
\text { mak belukar/rawa, Perta- } \\
\text { nian Lahan Kering }\end{array}$ & Rawan & $\begin{array}{c}\text { Kelas } \\
\text { Kerawanan } \\
3\end{array}$ \\
\hline $\begin{array}{l}\text { Hutan tanaman, perke- } \\
\text { bunan, Pertanian lahan } \\
\text { basah, Pertambangan, } \\
\text { Areal terbuka, Areal ter- } \\
\text { bangun }\end{array}$ & Sedang & $\begin{array}{c}\text { Kelas } \\
\text { Kerawanan } \\
2\end{array}$ \\
\hline $\begin{array}{l}\text { Hutan lahan kering pri- } \\
\text { mer, Hutan rawa primer, } \\
\text { Hutan mangrove primer }\end{array}$ & $\begin{array}{c}\text { Tidak } \\
\text { Rawan }\end{array}$ & $\begin{array}{c}\text { Kelas } \\
\text { Kerawanan } \\
1\end{array}$ \\
\hline
\end{tabular}

\subsection{Proses Weighted Overlay}

Proses Weighted Overlay merupakan proses pembobotan pada parameter-parameter yang telah dibuat. Proses Weighted Overlay dilakukan untuk pembobotan pada parameter yang telah memiliki pengkelasan dengan melakukan proses classify. Pada ketujuh data yang sudah melakukan proses classify, maka dapat dilakukan proses lebih lanjut untuk pembobotan 7 parameter data menjadi 
1 peta utama yaitu peta kerawanan kebakaran lahan dan hutan. Tujuh parameter yang digunakan berupa peta buffer jalan, peta buffer sungai, peta suhu permukaan, peta kepadatan hotspot, peta penutupan lahan, peta peruntukan lahan dan peta curah hujan yang sudah dilakukan proses classify. Tujuan dilakukanya proses Weighted Overlay yaitu untuk membuat keseluruhan parameter menjadi 1 data berdasarkan pembobotan masing-masing parameter sesuai dengan potensi persentase yang ditinjau melalui potensinya sebagai penyebab terjadinya kebakaran hutan dan lahan. Persentase parameter dapat di lihat pada tabel 7 .

Tabel 7. Persentase Pembobotan Weighted Overlay

\begin{tabular}{cc}
\hline Parameter & Persentase \\
\hline Suhu Permukaan & $29 \%$ \\
Curah Hujan & $29 \%$ \\
Kepadatan Hotspot & $18 \%$ \\
Peruntukan Lahan & $10 \%$ \\
Jaringan Sungai & $5 \%$ \\
Jaringan Jalan & $5 \%$ \\
Tutupan Lahan & $4 \%$ \\
\hline
\end{tabular}

\subsection{Pembuatan Peta Kerawanan Karhutla}

Pembuatan peta kerawanan karhutla dengan menggunakan proses Weighted Overlay. Weighted Overlay berfungsi untuk menganalisis berbagai jenis parameter yang kemudian disatukan menjadi satu kesatuan yang dapat mewakili keseluruhan parameter. Pembobotan pada Weighted Overlay dilakukan dengan membandingkan persentase tingkat potensi kerawanan antar berbagai parameter seperti yang terdapat pada tabel 7 . Parameter sebut dilakukan pada proses Weighted Overlay sebagai nilai influence, dan pengkelasan juga menjadi bahan pertimbangan untuk pembuatan peta kerawanan karhutla. Berdasarkan analisis melalui proses weight Overlay hasil dari pembobotan diklasifikasikan menjadi 3 kelas yaitu tidak rawan, rawan dan sangat rawan.

\section{HASIL DAN PEMBAHASAN}

Dari hasil pengolahan data-data sekunder dapat menghasilkan 7 peta sebagai parameter yang kemudian diolah menjadi peta kerawanan kebakaran hutan dan lahan berdasarkan pembobotan dengan menggunakan Weighted Overlay. Ketujuh parameter tersebut sebagai antara lain merupakan hasil proses Multiple Ring Buffer menunjukkan daerah Tanjung Jabung Barat memiliki rentan sungai yang saling berdekatan. Wilayah Tanjung Jabung Barat berada pada da-
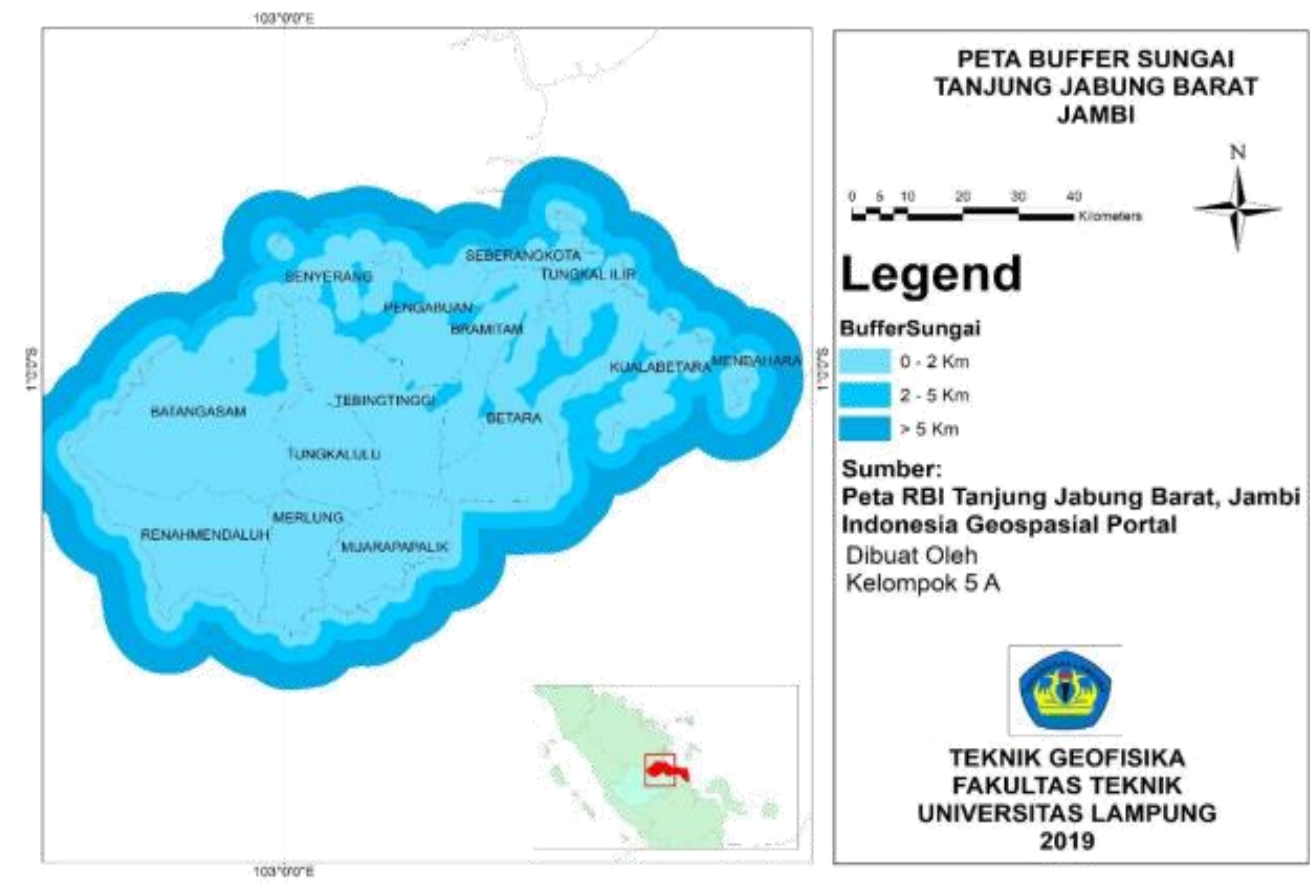

Gambar 1. Peta Buffer Sungai Tanjung Jabung Barat Provinsi Jambi yang terdiri dari rentang jarak 0-2 $\mathrm{Km}, 2-5 \mathrm{Km}$ dan $>5 \mathrm{Km}$.

erah berlingkup $0-2 \mathrm{Km}, 2-5 \mathrm{Km}$ dan $5-10 \mathrm{Km}$ (Gambar 1). Hutan dan lahan pada kawasan Tanjung Jabung Barat berada pada daerah lingkup jarak sungai $0-2 \mathrm{Km}$ dikarenakan secara lingkungan, Tanjung Jabung Barat didominasi oleh sungai yang berawa dengan cakupan wilayah yang cukup besar. Semakin dekat terhadap sungai maka akses pemadaman api semakin mudah. 

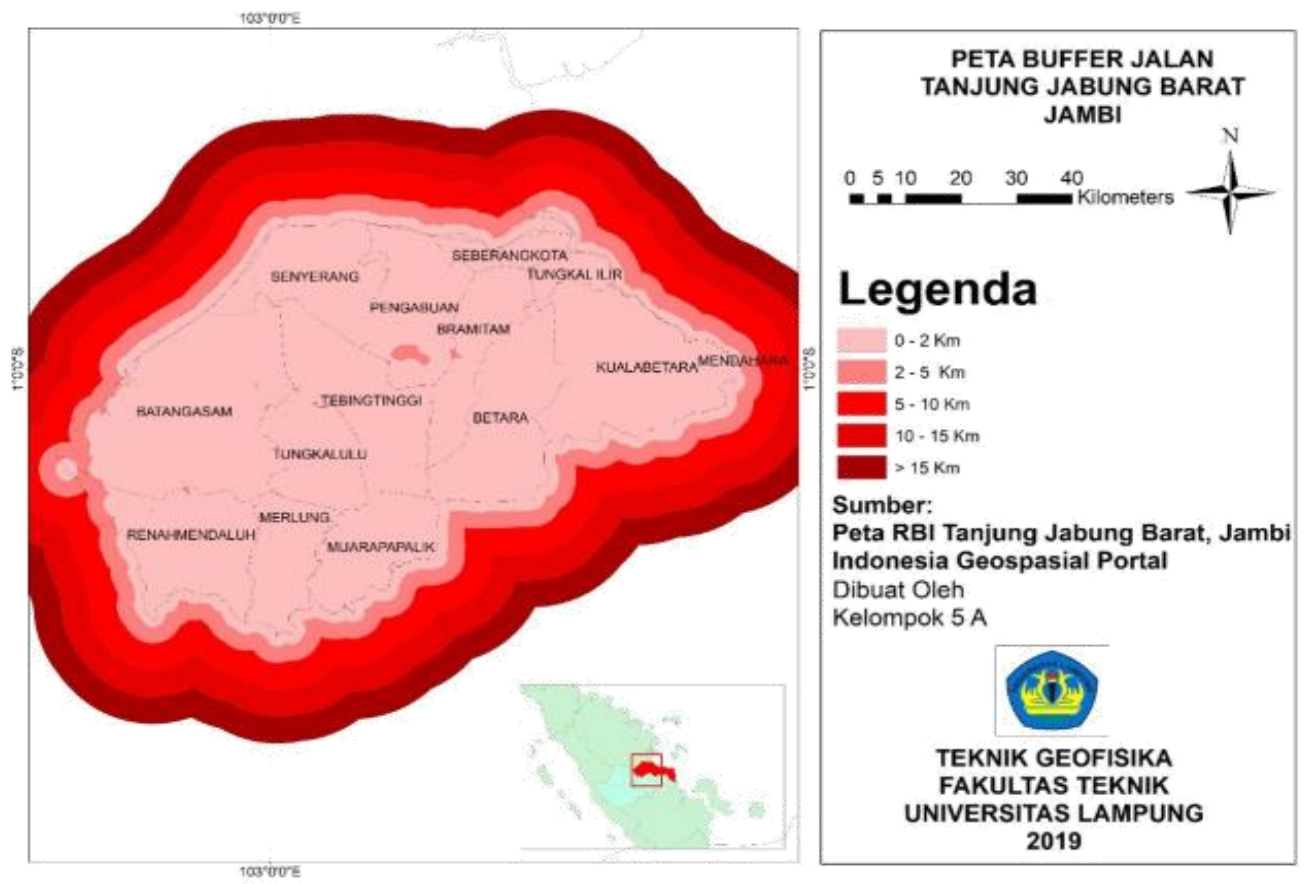

Gambar 2. Peta Buffer Jalan Tanjung Jabung Barat Provinsi Jambi yang terdiri dari rentang 0-2 Km, 2-5 $\mathrm{Km}, 5-10 \mathrm{Km}, 10-15 \mathrm{Km}$ dan $>15 \mathrm{Km}$.

Hasil dari proses Multiple Ring Buffer dengan interval jarak $0-2 \mathrm{Km}, 2-5 \mathrm{Km}, 5-10 \mathrm{Km}, 10-$ $15 \mathrm{Km}$ dan $>15 \mathrm{Km}$ pada data jalan ditunjukkan oleh Gambar 2. Daerah Tanjung Jabung Barat dengan jarak interval akses jalan antara satu dengan yang lain saling berdekatan, hal ini dikarenakan akses jalan di Tanjung Jabung Barat lebih dominan oleh jalan setapak untuk akses perkebunan warga. Semakin kecil interval antara jalan satu dengan yang lain maka dapat mengurangi potensi kerawanan kebakaran hutan dan lahan.
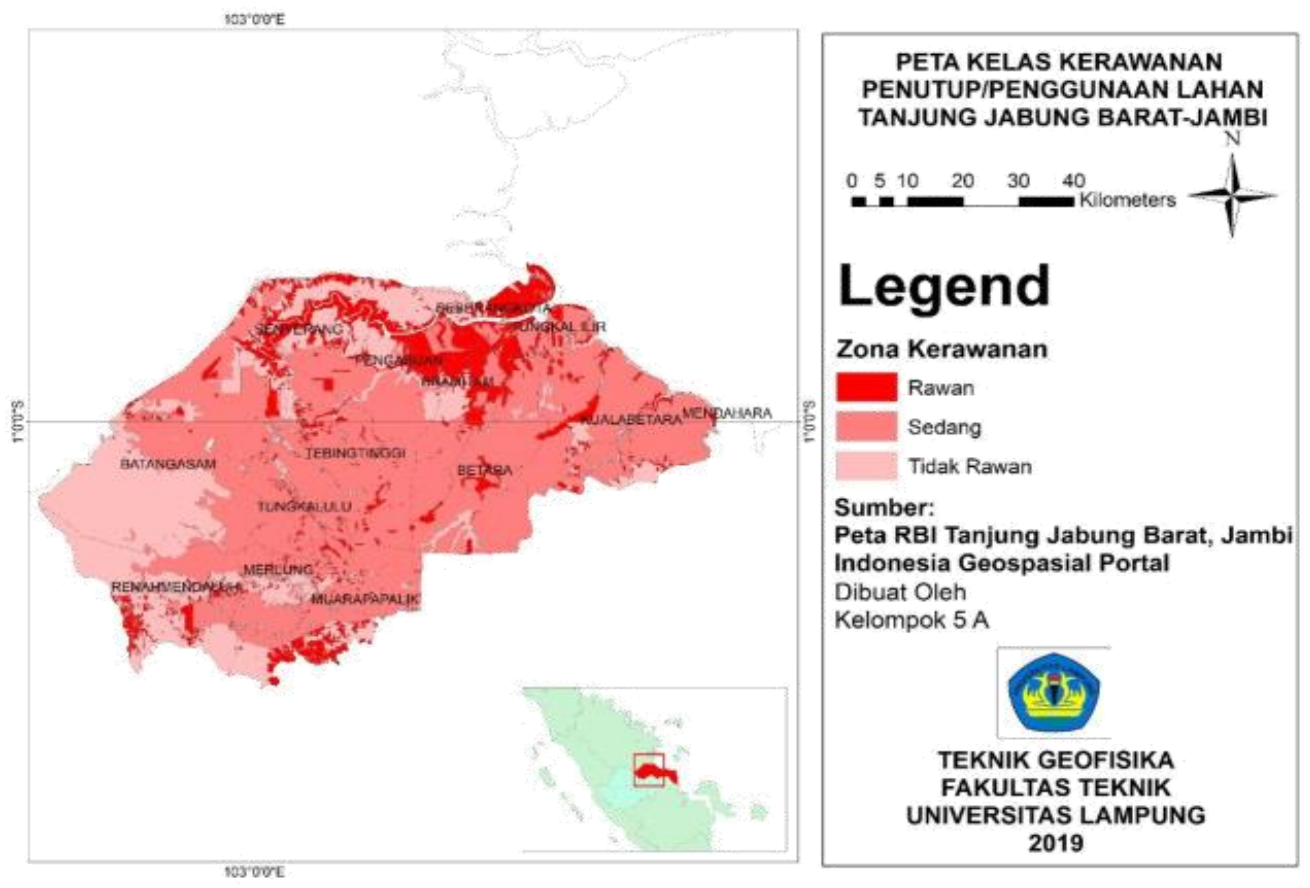

Gambar 3. Peta Tutupan/Penggunaan Lahan Tanjung Jabung Barat Provinsi Jambi yang terdiri dari rawan, sedang dan tidak rawan.

Hasil dari proses pembuatan peta penutupan lahan (Gambar 3) diperoleh 3 pengklasifikasian yaitu zona rawan, zona sedang dan zona tidak rawan. Pada zona sangat rawan ditiadakan dikarenakan wilayah Tanjung Jabung Barat tidak memiliki potensi penutupan lahan kelas 4 sesuai pada tabel 6. Lahan yang memiliki kelas rawan memiliki luas yang tidak mendominasi yaitu 100.196 ha. Pada lahan kelas kerawanan sedang dengan luas area yang mendominasi yaitu 250.391 ha. Berdasarkan lahan tidak rawan dengan luas 150.294 ha. Tingkat kerawanan dapat 
ditinjau berdasarkan kondisi lahan yang berpotensi menimbulkan terjadinya kebakaran hutan dan lahan. Pada zona kawasan rawan didominasi oleh adanya semak belukar dan pertanian lahan kering.
Pada zona kawasan sedang didominasi oleh adanya perkebunan warga. Sedangkan pada kawasan tidak rawan didominasi oleh adanya hutan mangrove primer dan hutan kering primer.
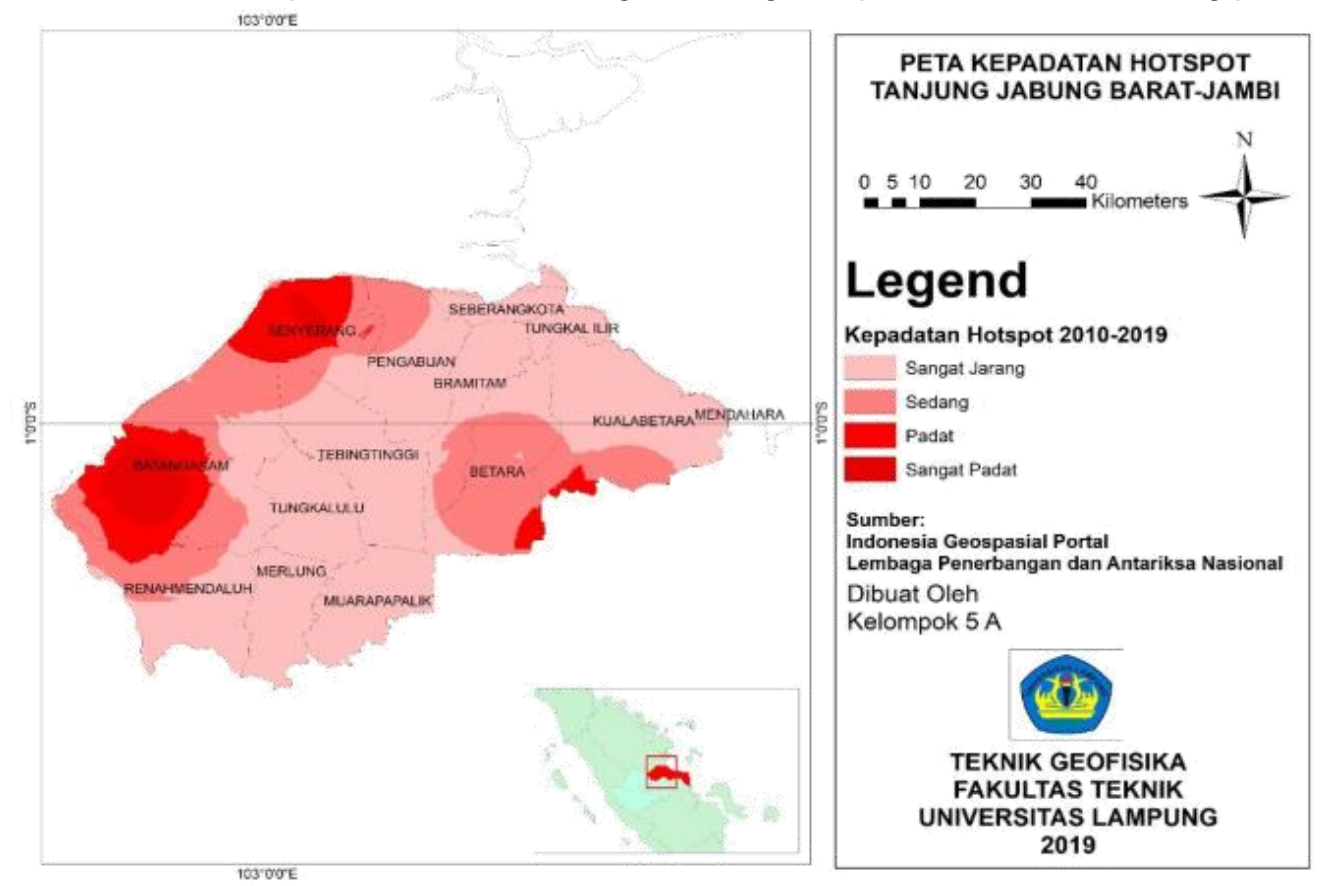

Gambar 4. Peta Kepadatan Hotspot Tahun 2010-2019 Tanjung Jabung Barat Provinsi Jambi yang terdiri dari sangat jarang, sedang, padat dan sangat padat.

Hasil dari proses pembuatan peta kepadatan hotspot (Gambar 4) dapat dikelaskan menjadi 4 parameter utama yaitu kepadatan sangat jarang, kepadatan sedang, kepadatan padat dan kepadatan sangat padat. Hasil yang menunjukkan terdapat 3 areal dengan kepadatan hotspot temporal sangat tinggi dapat diasumsikan bahwa kawasan ter- sebut sering terdapat titik panas. Titik panas dapat berupa pembakaran secara disengaja atau tidak disengaja maupun bekas pembakaran yang hidup kembali akibat keadaan cuaca, yakni berada di kawasan Desa Batang Asam, Desa Senyerang dan Betara dekat dengan perbatasan.
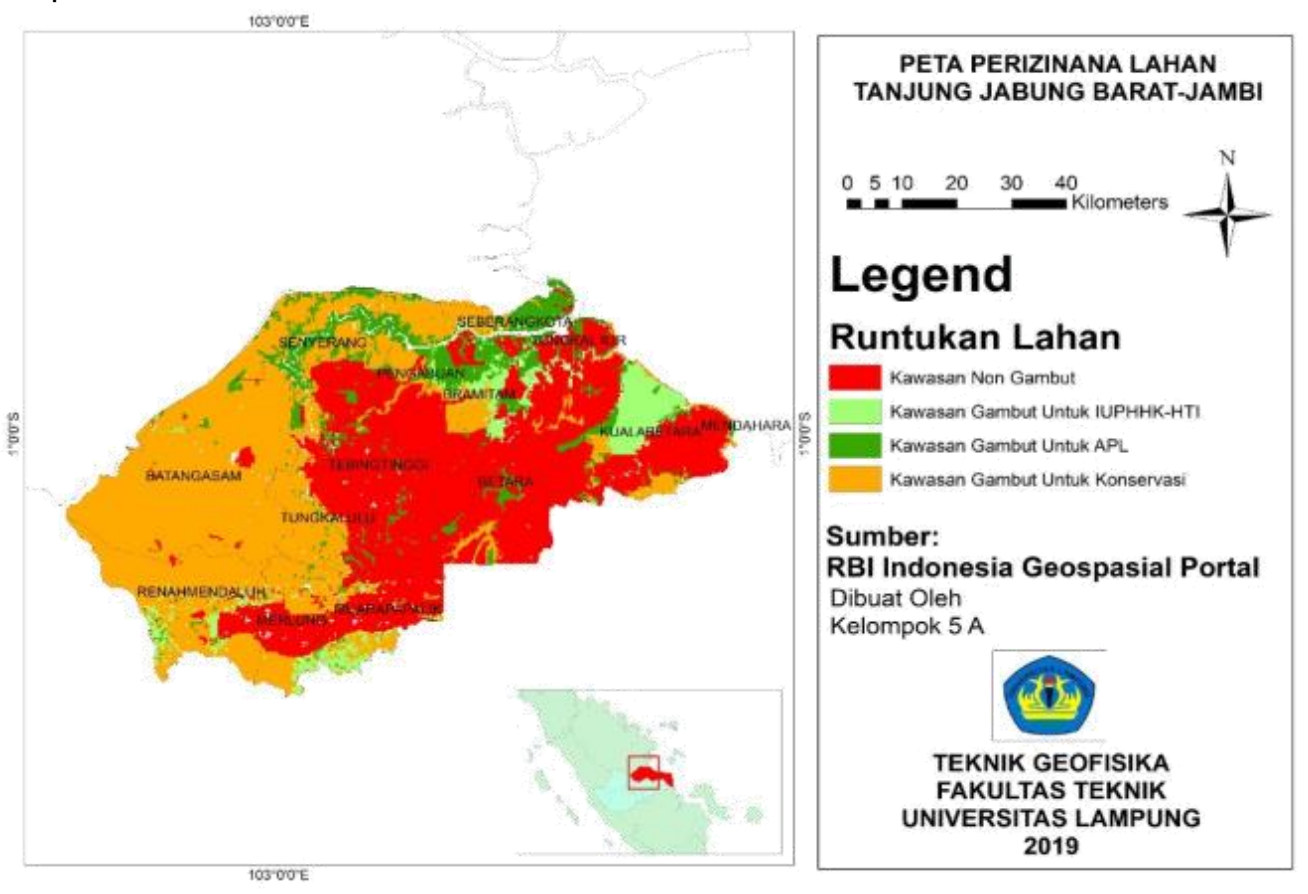

Gambar 5. Peta Perizinan Lahan Gambut Tanjung Jabung Barat Provinsi Jambi yang terdiri dari kawasan non gambut, kawasan gambut IUPHHK-HTI, kawasan gambut APL dan kawasan gambut konservasi. 
Berdasarkan hasil dari proses peta perizinan lahan gambut kawasan Tanjung Jabung Barat diklasifikasi menjadi 4 kerawanan (Gambar 5). Kawasan non gambut merupakan kawasan yang tidak berpotensi menimbulkan potensi kerawanan kebakaran hutan dan lahan dengan luas area 185.363 ha. Kawasan lahan gambut untuk konservasi merupakan lahan gambut yang dirawat serta dijaga untuk meminimalisir terjadinya kebakaran hutan dan lahan dengan luasan lahan gambut konservasi yaitu 165.324 ha. Kawasan la- han gambut IUPHHK-HTI merupakan kawasan lahan gambut yang memiliki izin untuk pemanfaatan hasil hutan memiliki tingkat kerawanan ke 3 dengan luas wilayah yaitu 60.117 ha. Kawasan lahan gambut APL merupakan kawasan yang sangat rawan untuk terjadinya potensi kebakaran hutan dan lahan dikarenakan lahan gambut APL yaitu lahan gambut terbuka tanpa adanya pengawasan dan perawatan sehingga berpotensi tinggi terjadinya kebakaran hutan dan lahan, luas lahan gambut APL yaitu 90.176 ha.
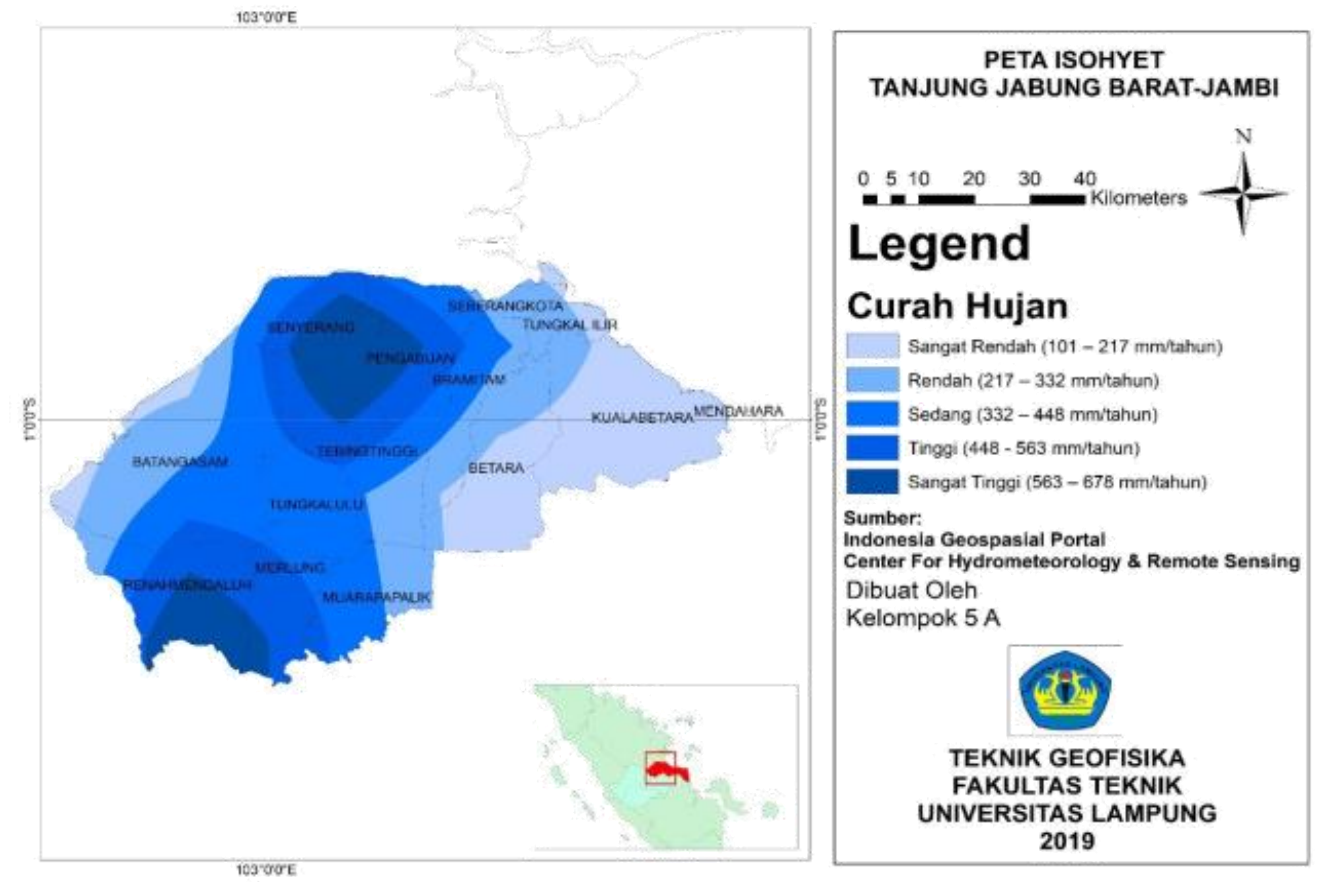

Gambar 6. Peta Curah Hujan Tahun 2018-2019 Tanjung Jabung Barat Provinsi Jambi dengan intensitas sangat rendah 101-217 mm/tahun, rendah 217-332 mm/tahun, sedang 332-448 mm/tahun, tinggi 448$563 \mathrm{~mm} /$ tahun dan sangat tinggi $563-678 \mathrm{~mm} /$ tahun.

Hasil dari proses interpolasi data curah hujan terhadap kawasan Tanjung Jabung Barat (Gambar 6) yang terdiri dari 5 pengklasifikasian yaitu sangat rendah, rendah, sedang, tinggi dan sangat tinggi. Curah hujan kawasan Tanjung Jabung Barat berkisar $101-678 \mathrm{~mm} / \mathrm{tahun}$ dengan tingkat curah hujan tertinggi pada daerah Renah mendalu. Wilayah yang rendah curah hujan maka akan berpotensi tinggi menjadi kawasan yang kemungkinan besar menjadi pusat panas sehingga dapat terjadinya kebakaran hutan dan lahan serta sulit mencari akses untuk memadamkan dengan skala yang sangat besar.

Kebakaran juga dapat terjadi karena suhu permukaan yang tinggi. Hasil menunjukkan (Gambar 7), daerah Tanjung Jabung Barat berada pada suhu $21-44^{\circ} \mathrm{C}$ yang kemudian diklasifikasikan menjadi 5 kelas kerawanan yaitu $21-25^{\circ} \mathrm{C}, 26-30^{\circ} \mathrm{C}, 31$ $35^{\circ} \mathrm{C}, 38-40^{\circ} \mathrm{C}$ dan $41-44^{\circ} \mathrm{C}$. Daerah dengan tingkat suhu permukaan tinggi berada pada Pengabuan, Bramitam, Kulabetara, Mendahara, Betara dan Tukang llir dengan rentan suhu $41-44^{\circ} \mathrm{C}$.

Proses pembobotan dalam metode Weight Overlay ditunjukkan untuk mengetahui bobot masing-masing parameter dengan pengklasifikasi- an serta persentase influence, yang selanjutnya dipetakan secara spasial sehingga dapat diketahui daerah-daerah yang terindikasi rawan akan kebakaran hutan dan lahan. Berdasarkan metode Weight Overlay dapat dilihat potensi masing-masing parameter yang menunjukkan potensi menimbulkan kebakaran hutan.

Berdasarkan tabel 7 diakumulasikan penjumlahan persentase $100 \%$ terhadap semua parameter yang dilakukan. Suhu dan curah hujan berpeluang tinggi dalam pembobotan berkisar $29 \%$ terhadap keseluruhan pembobotan. Hasil dari pembobotan yaitu menggabungkan semua parameter yang telah diklasifikasikan yang kemudian melakukan analisis Weighted Overlay. Hasil dari proses pembobotan menghasilkan peta kombinasi antara semua parameter yaitu peta kerawanan bencana kebakaran.

Berdasarkan peta hasil pengolahan sebelumnya, dilakukan proses Weighted Overlay, dengan melakukan proses pembobotan antara masingmasing peta dan menghasilkan peta dengan nilai bervariasi serta diklasifikasikan menjadi 3 parameter utama yaitu tidak rawan, rawan dan sangat 

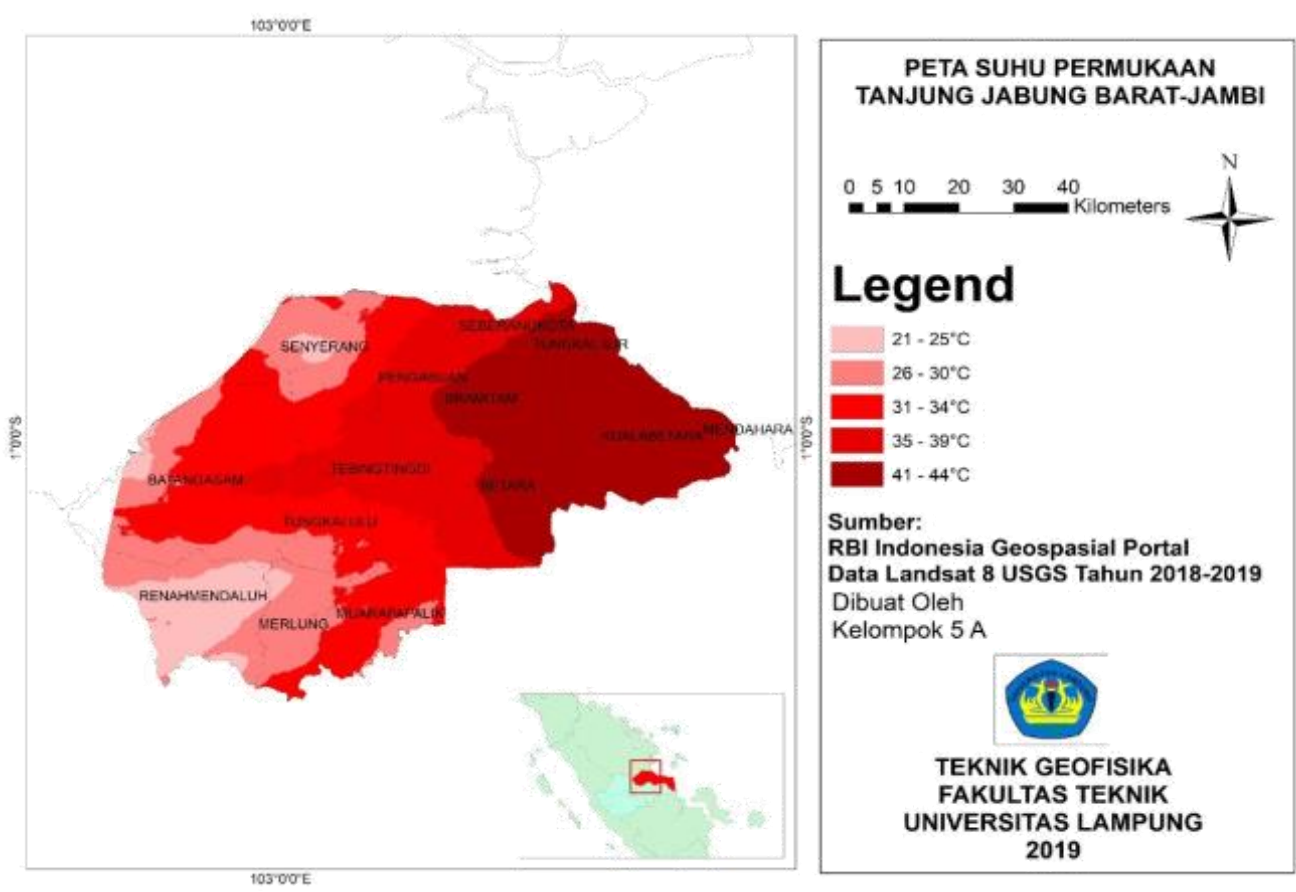

Gambar 7. Peta Suhu Permukaan Tanjung Jabung Barat Provinsi Jambi yang terdiri dari $21-25^{\circ} \mathrm{C}, 26-$ $30^{\circ} \mathrm{C}, 31-34^{\circ} \mathrm{C}, 35-39^{\circ} \mathrm{C}$ dan $41-44^{\circ} \mathrm{C}$.

rawan (Gambar 8). Daerah Tanjung Jabung Barat Provinsi Jambi memiliki tingkat kerawanan kebakaran hutan yang relatif rendah atau didominasi oleh kawasan tidak rawan hal ini dinilai berdasarkan faktor-faktor pembobotan dari masingmasing potensi yang berpengaruh terhadap kera-

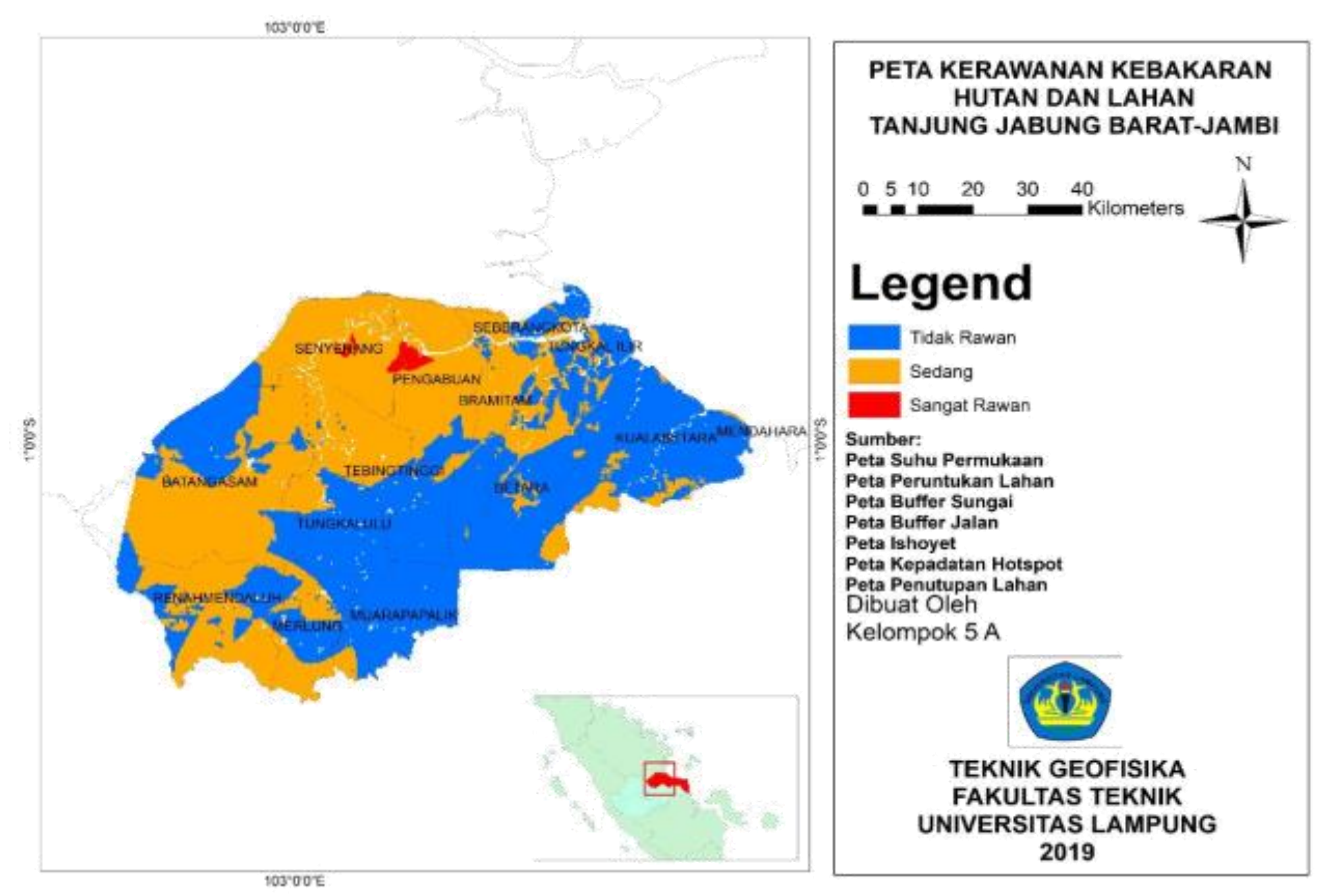

Gambar 8. Peta Kerawanan Kebakaran Hutan dan Lahan Tanjung Jabung Barat Provinsi Jambi yang terdiri dari tidak rawan, sedang dan rawan.

wanan kebakaran hutan dan lahan. Kawasan dengan tingkat rawan berada pada daerah Desa Senyerang dan Pengabuan dengan luasan 35.068 ha. Kawasan dengan tingkat sedang sangat mendominasi dengan luas daerah 200.392 ha. Kawasan dengan tingkat tidak rawan paling mendominasi dengan luas daerah 265.520 ha.

\section{KESIMPULAN}

Berdasarkan penelitian yang telah dilakukan maka dapat diambil kesimpulan parameter data curah hujan, data jaringan jalan, data jaringan sungai, data hotspot temporal, data peruntukan lahan, data suhu permukaan dan data penggunaan lahan sebagai parameter untuk analisis sistem 
informasi geografi agar mendapatkan peta kerawanan kebakaran hutan dan lahan. Parameter ini diolah dengan memanfaatkan koreksi citra untuk pengolahan citra Landsat 8, data spasial maupun data sekunder. Citra Landsat 8 sebagai media penginderaan jauh sering kali digunakan untuk melakukan pemantauan penggunaan lahan.

Berdasarkan proses Weighted Overlay, parameter yang berperan besar berupa suhu permukaan dan curah hujan. Provinsi Jambi memiliki musim kemarau yang lebih lama dibandingkan musim hujan, hal ini berpengaruh terhadap intensitas curah hujan pada kawasan Jambi sebagai parameter terbesar penunjang potensi kerawanan kebakaran hutan. Suhu permukaan mendukung terjadinya potensi kebakaran lahan dan hutan akibat tingginya suhu yang diberikan ke lahan gambut tanpa disertai curah hujan yang berintensitas tinggi.

Peta kerawanan kebakaran hutan disusun dengan sebuah skenario yaitu melakukan proses Weighted Overlay. Proses ini menggabungkan berbagai jenis parameter dengan persentase yang telah ditentukan untuk membentuk suatu peta kerawanan kebakaran hutan. Berdasarkan peta kerawanan kebakaran hutan terdapat 2 daerah yang berpotensi tinggi terjadinya kebakaran hutan yaitu pada daerah Desa Senyerang dan Pengabuan dengan intensitas sangat rawan.

\section{UCAPAN TERIMA KASIH}

Penulis mengucapkan terima kasih kepada rekan-rekan yang telah bekerja sama terhadap penelitian ini sehingga dapat terlaksanakan dengan sebaik-baiknya.

\section{DAFTAR PUSTAKA}

Andini, S. W., Prasetyo, Y., \& Sukmono, A. (2018). Analisis Sebaran Vegetasi Dengan Citra Satelit Sentinel Menggunakan Metode NDVI dan Segmentasi. Jurnal Geodesi Undip, 7(1), 14-24.

Delarizka, A., Sasmito, B., \& Hani'ah. (2016). Analisis Fenomena Pulau Bahang (Urban Heat Island) di Kota Semarang Berdasarkan Hubungan Antara Perubahan Tutupan Lahan Dengan Suhu Permukaan Menggunakan Citra Multi Temporal Landsat. Jurnal Geodesi Undip, 5(4), 165-177.
Fawzi, N. I. (2014). Pemetaan Emisivitas Permukaan Menggunakan Indeks Vegetasi. Jurnal IImiah Globe, 16(2), 133-139.

Kristianingsih, L., Wijaya, A. P., \& Sukmono, A. (2016). Analisis Pengaruh Koreksi Atmosfer Terhadap Estimasi Kandungan Klorofil-A Menggunakan Citra Landsat 8. Jurnal Geodesi Undip, 5(4), 56-64.

Masykur, F. (2014). Implementasi Sistem Informasi Geografis Menggunakan Google Maps Api Dalam Pemetaan Asal Mahasiswa. Jurnal Simetris, 5(2), 181-186.

Oktiana, C., Tjahjono, H., \& Sriyono. (2017). Hubungan Tingkat Pengetahuan Konservasi Lahan Gambut Dengan Tingkat Partisipasi Petani Dalam Upaya Pencegahan Kebakaran Lahan Gambut di Desa Gambut Jaya Kecamatan Sungai Gelam Kabupaten Muaro Jambi Tahun 2017. Jurnal Geografi FIS-UNNES, 6(2), 108-114.

Parman, S. (2010). Deteksi Perubahan Garis Pantai Melalui Citra Penginderaan Jauh di Pantai Utara Semarang Demak. Jurnal Geografi FIS-UNNES, 7(1), 30-38.

Rasyid, F. (2014). Permasalahan dan Dampak Kebakaran Hutan. Jurnal Lingkar Widyaiswara, 1(4), 47-59.

Sari, D. P., \& Lubis, M. Z. (2017). Pemanfaatan Citra Landsat 8 Untuk Memetakan Persebaran Lamun di Wilayah Pesisir Pulau Batam. Jurnal Enggano, 2(1), 39-45.

Syarif, A., \& Fitria. (2019). Increasing the Role as Well As Communities in The Construction of Forest Fire Through the Strengthening of Individual Institutions in Muaro Jambi District. Jurnal Karya Abdi Masyarakat, 3(2), 204-210.

Utomo, A. W., Suprayogi, A., \& Sasmito, B. (2017). Analisis Hubungan Variasi Land Surface Temperature Dengan Kelas Tutupan Lahan Menggunakan Data Citra Satelit Landsat (Studi Kasus: Kabupaten Pati). Jurnal Geodesi Undip, 6(2), 71-80.

Wahyunto, W., Masganti, M., Dariah, A., Nurhayati, N., \& Yusuf, R. (2014). Karakteristik dan Potensi Pemanfaatan Lahan Gambut Terdegradasi di Provinsi Riau. Jurnal Sumber Daya Lahan, 8(1), 59-66.

Widodo, R. B. (2014). Pemodelan Spasial Resiko Kebakaran Hutan (Studi Kasus Provinsi Jambi, Sumatera). Jurnal Pembangunan Wilayah \& Kota, 10(2), 127-138. 